\title{
The Development of Ethnobotany Based Local Wisdom Learning Materials to Improve Environmental Literacy and Creative Thinking Skills
}

\author{
Defita Permata Sari $^{1}$, Siti Sriyati ${ }^{2}$, Rini Solihat ${ }^{3}$ \\ \{defitapermatasari02@gmail.com ${ }^{1}$, siti_sriyati@yahoo.com ${ }^{2}$,rinisolihat@upi.edu ${ }^{3}$ \} \\ Indonesia University of Education, Bandung ${ }^{1,2,3}$
}

\begin{abstract}
Local wisdom of Keluru Village community for managing plant diversity in Temedak traditional forest could be internalized well through learning activity by using meaningful teaching materials in learning biology, especially those related to biodiversity utilization and strategies in biodiversity conservation. This study aimed to develop teaching materials based on ethnobotany local wisdom in the Temedak forest. The method in this study was descriptive qualitative. The design of teaching materials development used for the ADDIE approach. The subjects in this study were the community and traditional leaders of Keluru Village. The instruments used by the researcher for collecting the data were interview guides, field notes of observations, and the feasibility of teaching materials consist of content, graphics, presentation, and language based on the National Education Standards Agency (BSNP). The results indicated that the development of teaching materials which included local wisdom showed good and feasible in terms of material with a value of $85.13 \%$ (valid) and also feasible in terms of graphics with a value of $88.98 \%$ (valid). The conclusion was ethnobotany based local wisdom teaching materials in the Temedak forest could be applied in biology learning.
\end{abstract}

Keywords: ethnobotany, teaching materials, Temedak traditional forest, local wisdom

\section{Introduction}

In this century, the environment became a global issue that was interested to discuss and analyze. Since there was a lot of environmental damage caused by illegal logging and excessive use of natural resources without sustainable conservation [1]. One of these environmental problems could be found in Jambi Province. Jambi was one of 6 provinces in Indonesia were often occurs illegal logging, forest fires, and conversion of agricultural land [2]. Various studies showed that local communities' involvement in forest management has positive implications for forest sustainability.

Local people believed that human life was supported by the forests' existences, as the force of supernatural things that needed to be maintained to provide the benefits for human life [3]. High changing in lifestyle and human activities in utilizing forest products would significantly influence changed of forest ecosystems' function including the knowledge and understanding of the resources contained [4], by this reason a wise and balanced management was the only tool to maintain the values of the forest. One of the environmentally friendly forests had been 
carried out by the community of Keluru Village in Jambi Province by applied local wisdom to manage the plant diversity in the Temedak traditional forest.

Temedak traditional forest located in Jambi Province. Precisely, this forest located in Keluru Village, Kerinci Regency. Temedak traditional forest has an area of 23 ha and 500 meters away from residential areas. Local wisdom adopted by the Keluru village community to manage plant diversity in the Temedak forest has been proven to create an ecosystem balance. There were various awards which got by Keluru Village traditional institutions related to the environment.

The local wisdom of Keluru Village for managing plant diversity in the Temedak forest could be internalized well through learning by using meaningful teaching materials in learning biology, especially those related to the use of biodiversity and strategies to conserve biodiversity. It stated

in biology's material for class X which contained in basic competency 3.2 that analyzed various levels of biodiversity in Indonesia as the threats and preservation, and basic competence 4.2 that presented the results of observations in various levels of biodiversity in Indonesia and proposed conservation efforts.

Teaching material which has local materials could maximize students' absorption in learning material by provided direct examples of students' life would create more meaningful learning experience [5]. The development of teaching materials based on local wisdom could help both teachers and students in the learning process. Teaching materials based on local wisdom would improve students' environmental literacy in learning biology [6]. On the other hand, it generated ideas in environmental problem solving such as problems in biodiversity management, which needed students' thinking skills. One of the thinking skills that could support students' academic abilities through creative thinking skills.

\section{Method}

The design of teaching material development used a model with the ADDIE approach which consisted of five stages (analysis, design, development, implementation, and evaluation) [7].

In analysis stage, there were three things that researcher carried out, analyzed the local wisdom of Keluru Village community, especially those which related to the management of plant diversity in Temedak forest, endemic plants, corpse flower plants and plants that were generally used by the Keluru Village community; then analyzed Biology materials of class X high school in accordance with the concept of local wisdom in the management of plant diversity and ethnobotany; and analyzed the curriculum. The data of local wisdom in the Keluru Village community was collected through data triangulation which included observation, interviews, and literature studies.

In the designed stage the teaching materials had been designed based on the results of the analysis. Local wisdom which used to manage the Temedak forest integrated into the appropriate materials. At this stage, a map of the biological concept could be prepared to develop in macro and microstructures for teaching materials. As below there was the example of cover design in teaching materials that could be seen in Figure 1. 

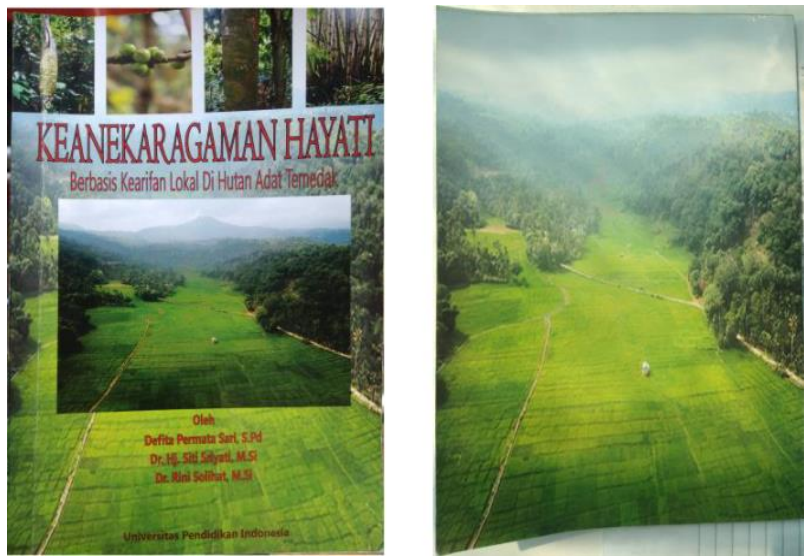

Fig. 1. Cover design of teaching materials: (a) front cover, (b) back cover.

In the third stage was the development of learning materials. At this stage, the development of teaching materials was carried out, then it proceeded with product validation. The aspects which assessed the validation of learning materials were content, language, graphics, and presentation.

The fourth stage was the implementation of teaching materials that could be applied in one of the State High Schools Kerinci. The evaluation stage assessed the results of the implementation of teaching materials in the form of textbooks. This stage was required for the importance of revision and known the appropriateness of teaching materials developed. The instruments used in this study were interview guides, field notes of observations, and the feasibility of teaching materials consisted of content, graphics, presentation, and language based on the National Education Standards Agency (BSNP). Data collection tools in this study were voice recorders and cameras. The data validation results of teaching materials by the validator had been analyzed through the mean score. The mean score based on the assessment criteria from the National Education Standards Agency (BSNP). Learning materials were feasible that assessed from material content and graphics with the following criteria:

1. The eligibility component had a minimum score of 2.75 for each subcomponent.

2. The validity, presentation, and graphic components had a minimum average of 2.50 for each component

\section{Result and Discussion}

\subsection{Result}

The expert validation aimed to determine the validity and feasibility of products which developed based on the opinions of experts ${ }^{[8]}$. The feasibility of the developed learning material was assessed by 3 expert lecturers in materials and 3 expert lecturers in technology. The results of the validation by these experts could be seen in Table 1 below.

Based on Table 1 it appeared that the assessment of the material experts obtained a mean score of 3.41 out of a maximum of 4.00 with a percentage score of $85.13 \%$. While the assessment of technology experts obtained a mean score of 3.55 out of a maximum of 4.00 with 
a percentage score of $88.98 \%$. Based on the category of the feasibility of teaching materials from the National Education Standards Agency (BSNP) consisted of the appropriateness of content, graphics, presentation, and language, the mean score above 2.75 was the valid category.

Table 1. Validation of Teaching Materials by Material Experts and Technological Experts.

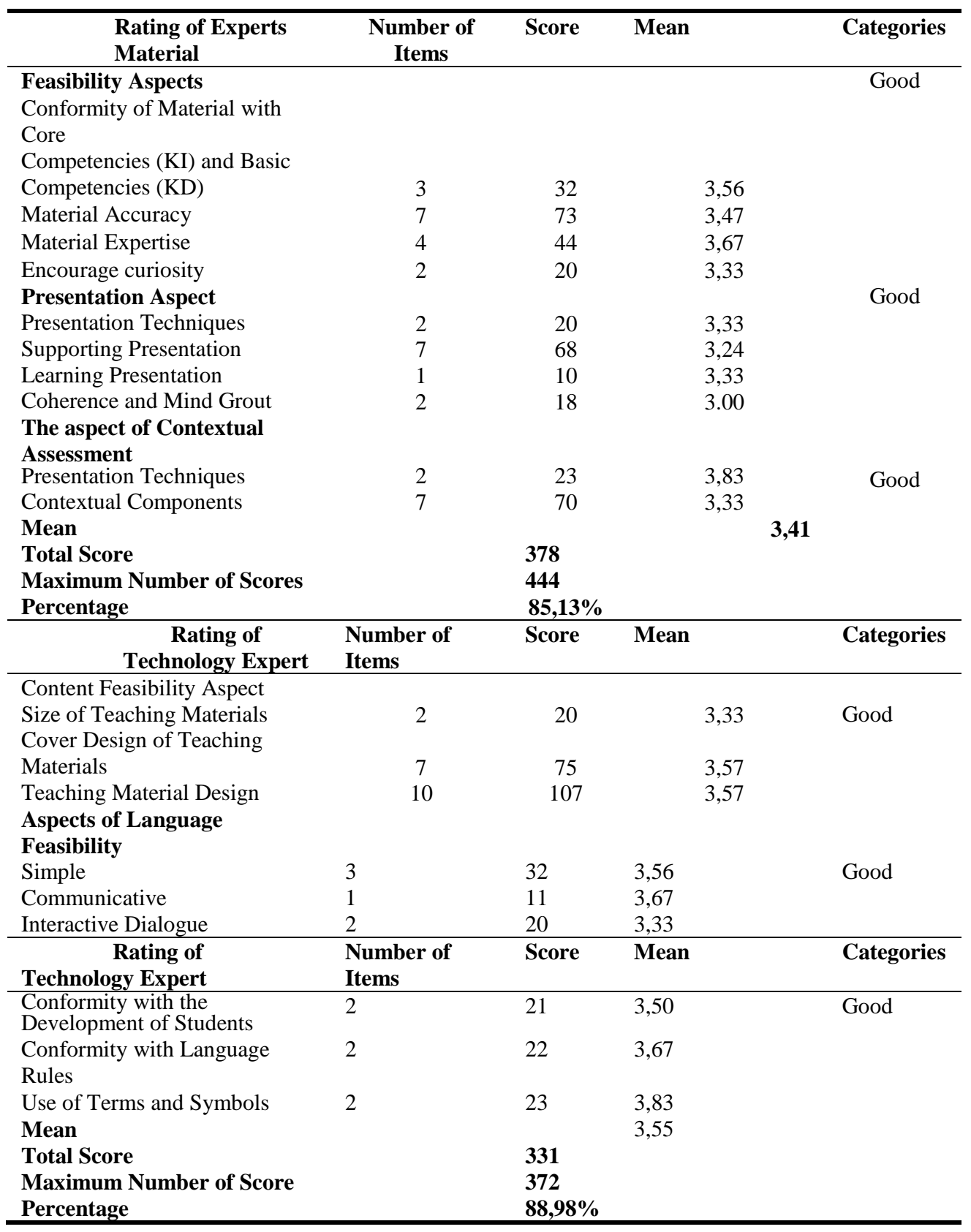




\subsection{Discussion}

The development of teaching materials based on ethnobotany local wisdom in the Temedak traditional forest that was developed. It could be helped teachers and students in the learning process. The teacher will not be focused on objects or examples that only exist in books, but teachers can show objects or real examples that exist in the environment around students themselves. ${ }^{[9]}$ Biology teachers should be able to present these objects significantly both in the classroom and structured tasks outside the classroom. Teaching materials developed were textbooks were expected to be able to give learning experience for students well, because biology learning was inseparable from nature and the living things in it so that these teaching materials can improve environmental literacy and creative thinking skills of students.

The developed learning materials had been validated by material experts and media experts. The results of teaching material developed were feasible and valid, so that were feasible to be used for high school students in class X. The results of the validation of the material experts as a whole got a percentage score of $85.13 \%$. The results of the material aspect indicated that teaching materials were worthy to use. The results obtained were inseparable from the content of the book that contained the material contextually and accompanied by visual images. ${ }^{[10]}$ The images contained in teaching materials have a positive effect on the ease of students to read and can increase understanding. The results of the overall assessment of media experts obtained a percentage score of $88.98 \%$. These results of the graphics aspect indicated teaching materials were worthy to use. ${ }^{[10]}$ There were four aspects that must be considered to design interesting teaching materials, namely contrast, layout, the arrangement of letters, and image design. These four aspects would determine the process of delivering messages in teaching materials to students.

The components that need to be considered in textbooks from physical or graphic aspects were typology, layout, cover, and illustration. These components were very influential in the interest of students to read and study teaching materials that would be developed ${ }^{[11]}$. The validator gave to assess in the form of numbers and also suggestions to be used as a basis for revisions towards teaching materials developed. There were some suggestions that had been obtained from material experts, namely glossary and answer keys of the questions contained in teaching materials should be showed on teaching materials, improve that were lack of teaching materials, the text of attitude development were solicitation sentences should be showed on the teaching materials. Then the advice from the graphic expert was the size of the illustration should be proportional, the cover was reorganized, the font size was cross-checked again, the use of words "you" and "we", should be checked again so the reader did not confuse.

\section{Conclusion}

The teaching material based on local wisdom ethnobotany in the Temedak traditional forest had been developed successfully and had passed the validation stage from the experts of material and technology. The feasibility of teaching materials could be seen from the ability of teaching 
materials which had the eligibility assessment standards based on the National Education Standards Agency (BSNP) that consisted of content, graphics, presentation, and language. Based on the results of the study, the teaching materials were developed which included local wisdom showed good and decent results in terms of material with a value of $85.13 \%$ and feasible in terms of language with a value of $88.98 \%$. The conclusion that the development of ethnobotany teaching materials based local wisdom in Temedak traditional forest could be used for biology learning and were suitable to use by grade $\mathrm{X}$ high school students.

Acknowledgments. The researcher would like to thank the community in Keluru Village, especially the traditional leaders of Keluru Village who have provided assistance and information related to local wisdom in the Temedak traditional forest. Then I also thankful to University Pendidikan Indonesia whose granted permission to conduct this study and others who helped to carry out this study and produced teaching materials that could be used for high school students in grade $\mathrm{X}$.

\section{References}

[1] Nasution, R.: Analisis Kemampuan Literasi Lingkungan Siswa SMA Kelas X Di Samboja Dalam Pembelajaran Biologi. Proceeding Biology Education Conference, 13(1), hlm. 352-358 (2016)

[2] Kementrian Lingkungan Hidup.: Survey Perilaku Peduli Lingkungan Hidup 2013. Badan Pusat Statistik, Jakarta (2013)

[3] Sari, D. A.: Etnoekologi Masyarakat Kerinci Di Kabupaten Kerinci Provinsi Jambi. (Tesis). Sekolah Pascasarjana, Universitas Indonesia Depok (2011)

[4] Rahayu, M., Susiarti, S., and Purwanto, Y.: Kajian Pemanfaatann Tumbuhan Hutan Non-Kayu Oleh Masyarakat Lokal di Kawasa Konservasi PT. Wira Karya Sakti Sungai Tapa-Jambi. Jurnal Biodiversitas, 8(1), hlm. 73-78 (2007)

[5] Yonanda, D. A.: Pengembangan Bahan Ajar Mulok Berwawasan Kearifan Lokal Indramayu Untuk Siswa Kelas IV Sekolah Dasar. Prosiding Seminar Nasional Pendidikan Dasar. hlm. 210-215. Bandung: Sekolah Pascasarjana, Program Studi Pendidikan Pendidikan Dasar (2016)

[6] Subhan, A.: Pengembangan Bahan Ajar Berbasis Nilai-Nilai Kearifan Lokal Pertanian Padi di Cirebon untuk Meningkatkan Literasi Lingkungan Siswa SMP. (Tesis). Sekolah Pascasarjana, Universitas Pendidikan Indonesia, Bandung (2017).

[7] Sugiyono.: Metode Penelitian dan Pengembangan. hlm. 38-19. Alfabeta, Bandung (2015)

[8] Prabowo, C. A., Saptasari, M., Ibrohim.: Pengembangan Modul Pembelajaran Inkuiri Berbasis Laboratorium Virtual. Jurnal Pendidikan, 1(6), hlm. 1090-1097 (2016)

[9] Mumpuni, K. E. Potensi Pendidikan Keunggulan Lokal Berbasis Karakter Dalam Pembelajaran Biologi Di Indonesia. Seminar Nasional X Pendidikan Biologi FKIP UNS. hlm. 1-7. Surakarta: Pendidikan Biologi UNS (2013).

[10] Rotter, K. Creating Instructional Materials for All Pupils: Try COLA. Intervention in School and Clinic. 41(5), hlm. 273-282 (2006)

[11] Supriadi, D. Anatomi Buku Sekolah di Indonesia: Problematika Penilaian, Penebaran, dan Penggunaan Buku Pelajaran, Buku Bacaan, dan Buku Sumber. Adicipta, Yogyakarta 